\title{
Functional Morphology of the Utilization \\ of Starch Grain by Rumen Entodiniid \\ Ciliates In Vitro
}

\author{
Masayasu KInoshita, Soichi ImaI, Toshio IshII \\ and Keiji Ogrmoto* \\ Department of Parasitology, Nippon Veterinary and \\ Zootechnical College, Musashino-shi 180 \\ *Department of Animal Science, Tohoku University, \\ Sendai-shi 980
}

(Received May 11, 1984)

\begin{abstract}
Degradation of starch grains by entodiniid ciliates from a goat rumen was investigated morphologically in vitro. The ciliates obtained from the culture were stained with iodine and PAS stain for light microscopy, or treated by resin-pulverizing method for scanning electron microscopy. When the ciliates were cultured with various kind of starch grain, favorable maintenance of the ciliates was done when the smaller grains, such as rice strach, were added in the culture. It indicates that the ability of assimilation of starch is closely related to the size of starch grain. The starch grains added were taken very quickly in the ciliate body (within 5 minutes). After that, the grains became smaller gradually, and disappeared about 72 hours after. Following the contraction of starch grains, PAS positive fine grains were noticed in the ectoplasm of ciliate. From the result that these fine grains disappeared in the starvation culture, it seemed that these grains were reserve materials for the rumen entodiniid ciliates.
\end{abstract}

Jpn. J. Zootech. Sci., 55 (11): 864-876, 1984

It is well known that rumen ciliates utilize various carbohydrates ${ }^{1}$, and that the ophryoscolecid ciliates occupying a greater part of the ciliates in the rumen require particulate carbohydrates ${ }^{2,3)}$. It is also reported that only large ophryoscolecid ciliates of them, such as Diplodinium, Eudiplodinium and Polyplastron, can degradate cellulose, but other ciliates can not use it as their nutrient ${ }^{4,5}$. Thus, the almost only carbohydrate nutrient for the ciliates belonging to the genus Entodinium, which have a majority in the rumen ciliates, has been suggested to be starch grain ${ }^{6}$.

This report presents the results of the examination on the influence of various starch added as a nutrient to the media, and of light and scanning electron microscopical observations on the degradation of wheat starch grains in the in vitro cultivation of entodiniid ciliates.

\section{Materials and Methods}

1. Source of protozoa

Rumen contents were collected using a rumen catheter from an adult goat kept at the Nippon Veterinary and Zootechnical College. The contents collected were squeezed with double folded sheet of muslin. Then the filtrate was immediately lapped 
with Sealon Film (Fuji Photo Film Co.) and incubated at $39^{\circ} \mathrm{C}$ for 1 h. The fine food residue floated at upper part of the filtrate during incubation was removed by aspiration, then the recovered fluid were used as the inoculation source of rumen ciliates. The recovered fluid contained $2.8 \times 10^{\circ} / \mathrm{m} l$ ciliates consisted of 3 genera, Entodinium, Diplodinium and Dasytricha.

\section{Starch added}

Five kinds of starch, rice starch, wheat starch, corn starch, soluble starch and potato starch, were examined for the growth of entodinia in vitro. To make uniform the size of grain in each starch as possible, each kind of starch was suspended in distilled water and centrifuged at $500 \mathrm{G}$ for $10 \mathrm{~min}$. Then middle layer of starch was collected. The recovered starch was dried at $37^{\circ} \mathrm{C}$ and resuspended in Hungate's salts solution ${ }^{7)}$ as $0.1 \%$ of the concentration.

\section{Cultivation}

The cultivation system was in accordance with the simple culture system using Hungate's salts solution ${ }^{8,9)}$. This culture system was developed for the purpose of cultivating the ciliates for relatively short period, and the dried grass and rumen fluid in the inoculation source were added as nitrogen source. However, in the present examination dried grass was eliminated from the system except positive control to examine the effect of starch clearly.

Fifty milliliter of Hungate's salts solution $\left(39^{\circ} \mathrm{C}\right)$ was poured into $100 \mathrm{~m} l$ vaccine bottle in $39^{\circ} \mathrm{C}$ water bath, and passed mixed gas $\left(\mathrm{N}_{2}: \mathrm{CO}_{2}=95: 5\right)$ for 3 min. As final ciliate number became about $5,000 / \mathrm{ml}$ in the media, proper quantity of protozoa source was inoculated into the media then the mixed gas was passed for 1 min. After that, each bottle was sealed with a butyl rubber stopper, and cultured in an $39^{\circ} \mathrm{C}$ incubator.

Everyday, while passing mixed gas, $2 \mathrm{ml}$ of the medium was collected for the examination of the ciliate population. After that, $0.5 \mathrm{ml}$ of $39^{\circ} \mathrm{C}$ starch solution and $1.5 \mathrm{ml}$ of $39^{\circ} \mathrm{C}$ HunGate's salts solution were added into the media. Collected samples were fixed and stained with MFS (methylgreen-formalin-saline) solution ${ }^{10}$. The number of ciliates was calculated with a plankton counter deck glass (Rigosha, Tokyo) on which the lines were cut at $0.5 \mathrm{~mm}$ intervals. The culture added $2.0 \mathrm{ml}$ of HunGATE's salts solution instead of starch solution was also examined as a negative control. As a positive control, the same cultures as that reported by IMAI et al. ${ }^{8,9)}$ was prepared.

\section{Observations of ingested starch grains in Entodinium}

The rumen contents mentioned above were added to equal volume of $39^{\circ} \mathrm{C} \mathrm{HuN}$ GATE's salts solution. After gassing $\left(\mathrm{N}_{2}+\mathrm{CO}_{2}\right)$ for $2-3 \mathrm{~min}$, the contents were set on an $39^{\circ} \mathrm{C}$ incubator for $24 \mathrm{~h}$. This was used as the inoculation source of protozoa. Cultivation system was in accordance with the simple culture system using Hungate's salts solution ${ }^{8,9}$. The ciliate source was inoculated so as to become about $5,000 / \mathrm{m} l$ in ciliate number, then mixed gas was passed into the medium, and $0.5 \mathrm{~m} l$ of pre- 
pared wheat starch solution was added. The culture bottle was sealed with a butyl rubber stopper, and cultured in an $39^{\circ} \mathrm{C}$ incubator.

Samples for microscopical examination were collected from the ciliate source and the culture vessels immediately, $5 \mathrm{~min}$ and $1,3,6,9,12,24,48,72$ and $96 \mathrm{~h}$ after addition of starch. A part of each sample was fixed with $10 \%(\mathrm{~V} / \mathrm{V})$ formalin solution and stained with iodine or PAS stain for light microscopy. The other part of the samples was prepared for scanning electron microscopy (SEM) in accordance with the resin-pulverizing method by IMAI and TASHIRo ${ }^{11}$.

\section{Results}

1. Effect of the kind of starch on the growth of ciliates

The ciliate growth in the cultivation added various kinds of starch is shown in Fig. 1.

The total ciliate number in each cultivation in which about $5,500 / \mathrm{m} l$ of ciliates

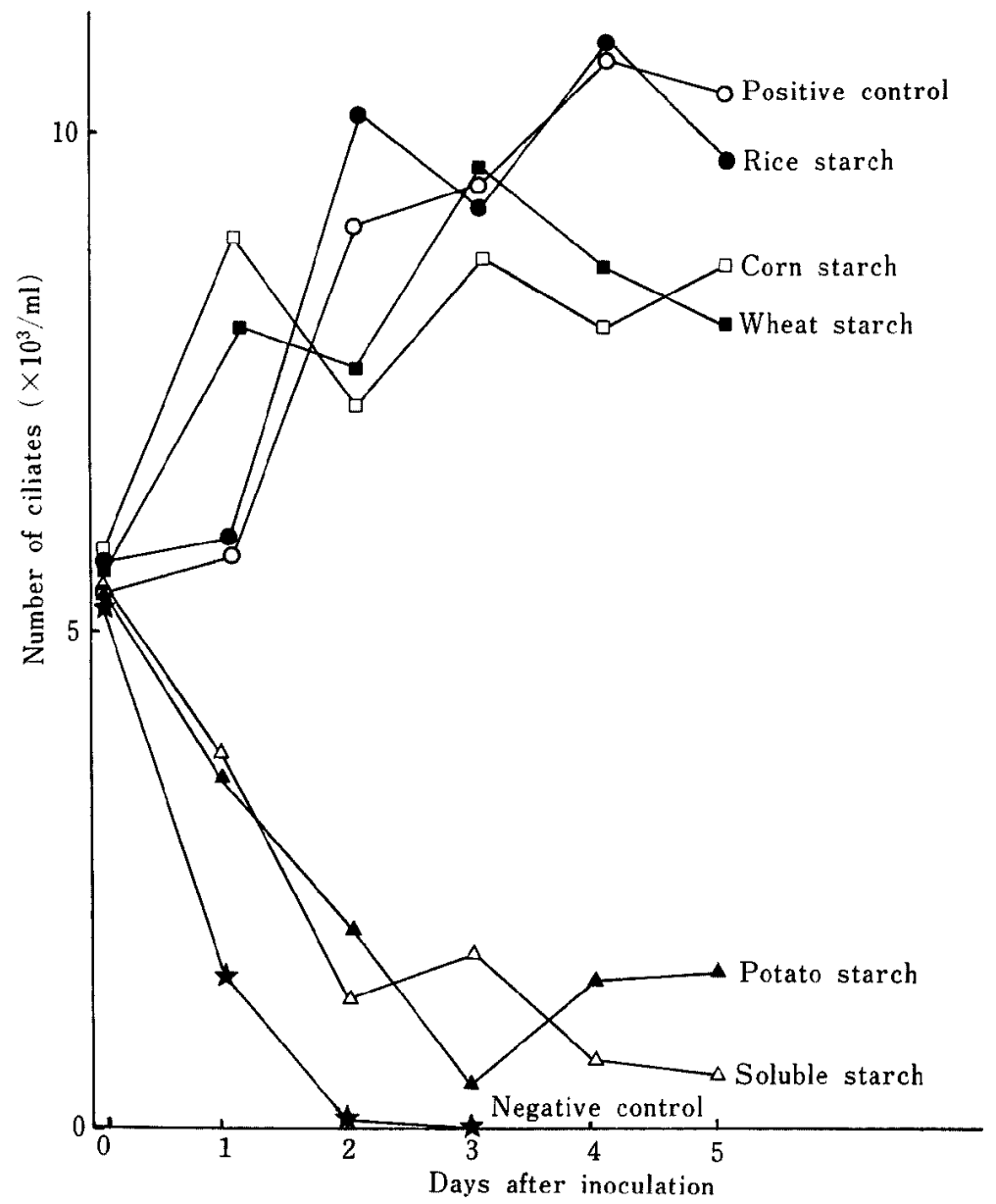

Fig. 1. Changes in the number of rumen ciliates fed various kinds of starch grains in vitro. 
were inoculated at the start showed various changes. The growth of ciliates was the best in the culture with rice starch and positive control, or the ciliate numbers in both cultures became about $10,000 / \mathrm{ml}$ at 5 days after inoculation. The secondly good growth of ciliates was obtained from the cultures with corn starch and wheat starch, and the number became about $8,000 / \mathrm{m} l$ at 5 th day. In contrast, the ciliate number in the cultures with soluble starch and potato starch decreased gradually and at 5 days after inoculation it became under $1,000 / \mathrm{ml}$. In the negative control, ciliates disappeared at 3 days after inoculation.

Of the ciliates, entodinia showed the increase in number in the cultures except with soluble starch, potato starch and negative control, but the number of ciliates belonging to the genera Diplodinium and Dasytricha decreased in every culture. Of them, Entodinium caudatum showed the best growth in positive control, and the number increased 5.2 times of it at start.

Six species of entodinia, Entodinium minimum, E. parvum, E. nanellum, E. simplex, E. caudatum and $E$. ovinum, were found in the inoculation source. The

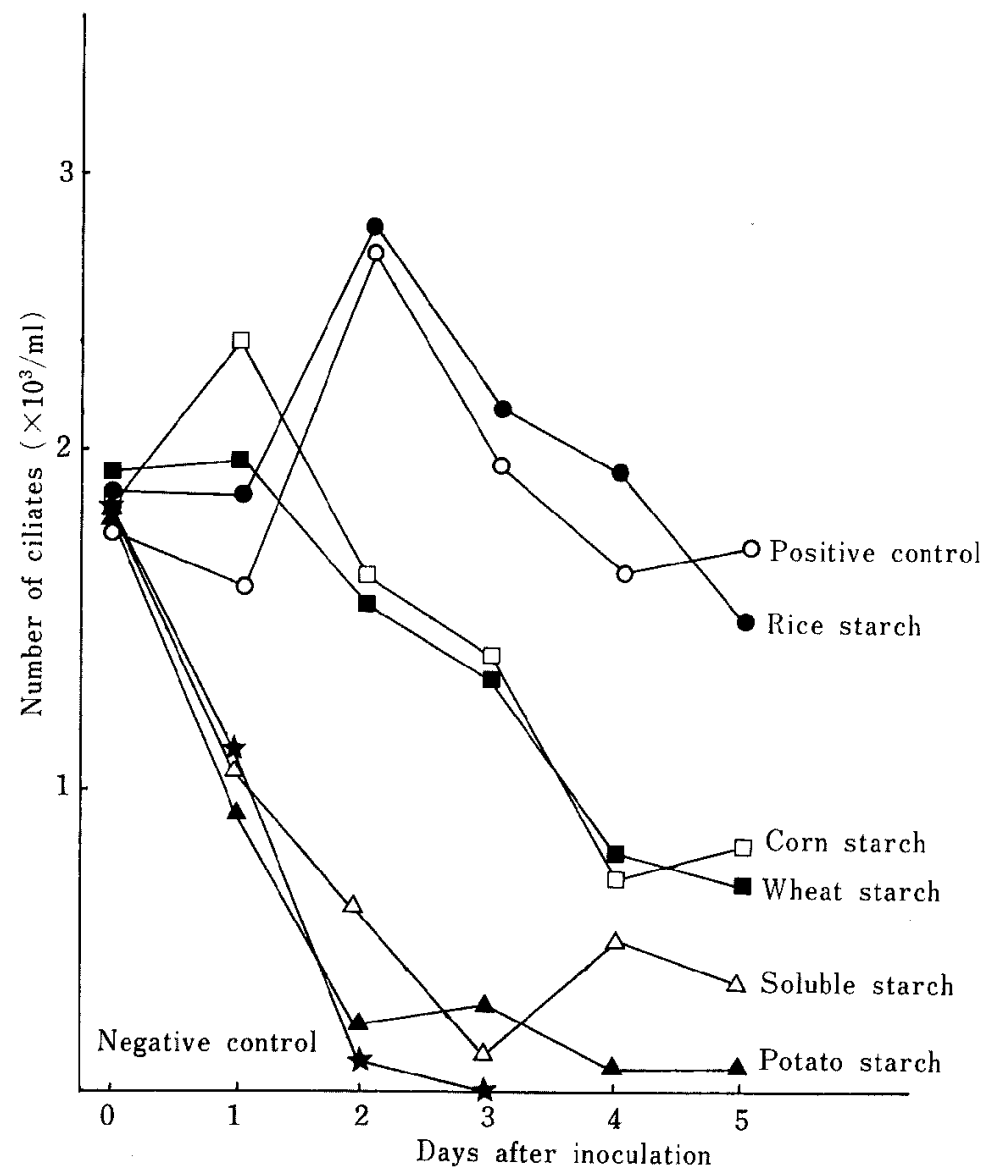

Fig. 2. Changes in the number of small entodinia fed various kinds of starch grains in vitro. 
former 3 species were gathered as small entodinia because of their small size and the latter 3 species as large entodinia because of their relatively large size. The growth curve of the small entodinia is shown in Fig. 2, and of large entodinia in Fig. 3, respectively. The growth of small entodinia, of which the number was about 2,000 / $\mathrm{m} l$ at start of cultivation, was divided into 3 types regarding to the kind of starch added-one was a type in positive control and the culture with rice starch, in which the ciliate number was about $3,000 / \mathrm{ml}$ at $3 \mathrm{rd}$ day and after that decreased to nearly $1,700 / \mathrm{ml}$, another was a type in the cultures with wheat starch and corn starch, in which the ciliate number decreased from 2 nd day and became nearly $700 / \mathrm{m} l$ at 5 th day, and the other was a type in the cultures with potato starch, soluble starch and negative control, in which the ciliate number decreased gradually and became under $500 / \mathrm{ml}$ at 5 th day.

On the other hand, there were also two types in the growth curve in large entodinia, one was a type in positive control and the cultures with rice starch, wheat starch and corn starch, in which the ciliate number was about $4,500 / \mathrm{ml}$ at start of

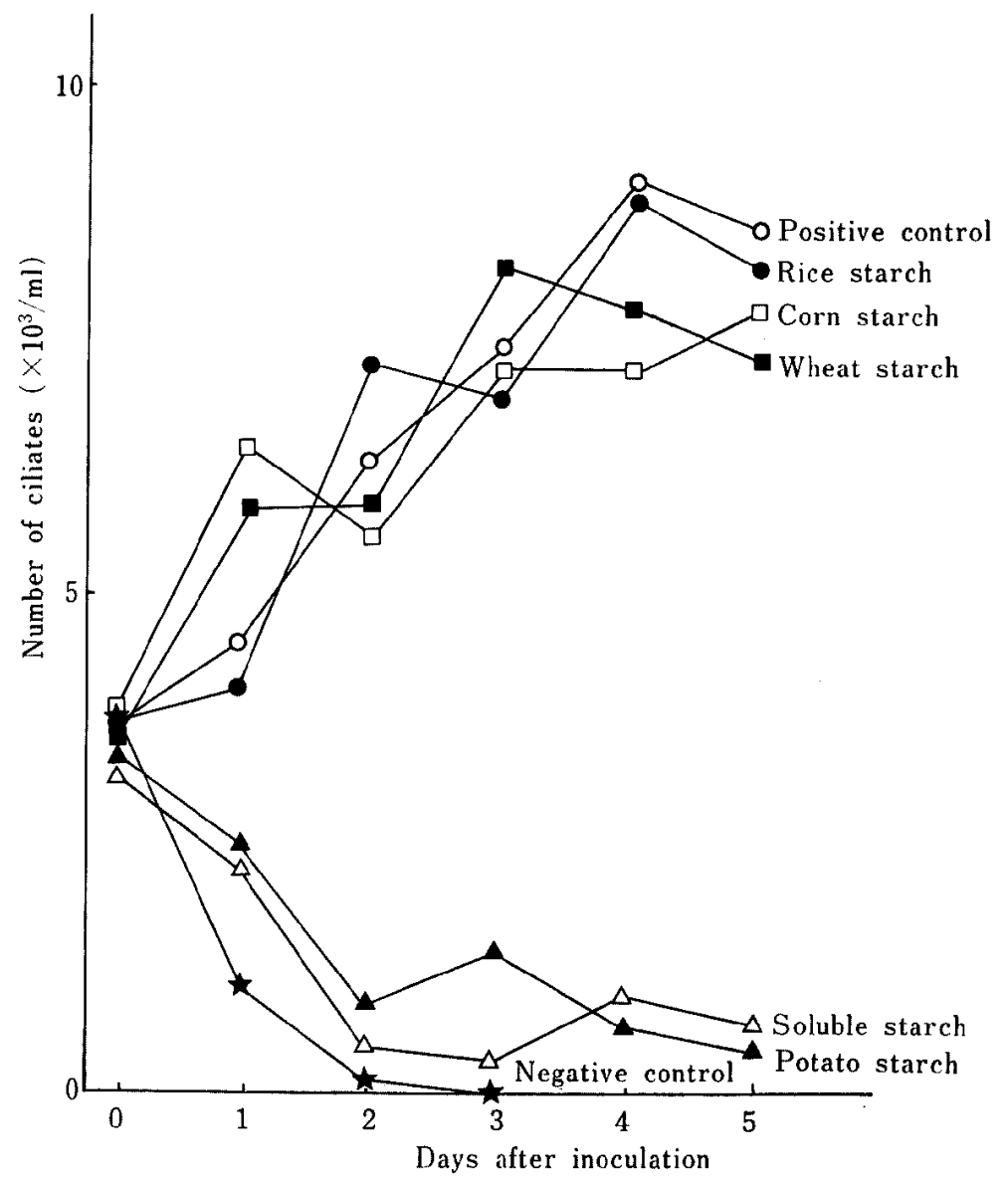

Fig. 3. Changes in the number of large entodinia fed various kinds of starch grains in vitro. 
cultivation and increased to over $7,000 / \mathrm{ml}$, and the other one was a type in the cultures with potato starch, soluble starch and negative control, in which the ciliate number decreased under $1,000 / \mathrm{ml}$.

From the result that there was a difference in the survivability of ciliates regarding to the kinds of starch added and the ciliate species, it was suggested that the ability of assimilation of starch grains by the ciliates was closely related to the sizes of ciliate's mouth and of starch grains. Then, the sizes of each oral zone of ciliates and of each starch grain were measured microscopically. The result is shown in Table 1.

Table 1. Relation between the sizes of the oral zone of ciliates and of the starch grains

\begin{tabular}{|c|c|c|c|c|c|c|}
\hline $\begin{array}{l}\text { Ciliate } \\
\text { species } \\
\text { Kind of } \\
\text { starch }\end{array}$ & $\begin{array}{r}\text { Entodinium } \\
\text { nanellum } \\
16.0 \mu \mathrm{m}^{*}\end{array}$ & $\begin{array}{r}\text { E. } \operatorname{minimum} \\
21.1 \mu \mathrm{m}\end{array}$ & $\begin{array}{r}\text { E. paroum } \\
24.6 \mu \mathrm{m}\end{array}$ & $\begin{array}{r}\text { E. ovinum } \\
32.6 \mu \mathrm{m}\end{array}$ & $\begin{array}{r}\text { E. simplex } \\
32.7 \mu \mathrm{m}\end{array}$ & $\begin{array}{r}\text { E. caudatum } \\
39.5 \mu \mathrm{m}\end{array}$ \\
\hline $\begin{array}{r}\text { Rice starch } \\
4.4 \mu \mathrm{m}^{*}\end{array}$ & & & & & & \\
\hline $\begin{array}{r}\text { Wheat starch } \\
9.7 \mu \mathrm{m}\end{array}$ & & & & & & \\
\hline $\begin{array}{r}\text { Corn starch } \\
10.9 / / \mathrm{m}\end{array}$ & & & & & & \\
\hline $\begin{array}{r}\text { Soluble starch } \\
40.9 \mu \mathrm{m}\end{array}$ & & & & & & \\
\hline $\begin{array}{r}\text { Potato starch } \\
45.7 \mu \mathrm{m}\end{array}$ & & & & & & \\
\hline
\end{tabular}

Remarks: (1) White circles indicate the case that the oral zone of ciliate is larger than the starch grain, in contrast, black circles indicate the reverse case. (2) Arrows show the result of ciliate growth in vitro in the indicated assortment. The arrows upward indicate increase, and that downward the decrease of ciliate number. (3)*: Average diameter of the oral zone of ciliates or of the starch grains.

2. Observation of engulfed starch grains by entodinia

In the ciliates starved for $24 \mathrm{~h}$, both the ectoplasm and endoplasm were stained light yellowish by iodine staining (Fig. 4) and light reddish by PAS stain. The broken surface with SEM of the ciliates at the same condition was relatively homogenous and no granular substances were observed.

Starch grains added into the media were ingested immediately by most of entodinia within 5 min (Figs. 5 and 6). At that time, the starch grains ingested by the ciliates were stained dark violet by iodine staining, whereas no characteristic staining condition was observed at the other parts of ciliates in both iodine staining 


\section{Kinoshita, ImaI, Ishil and OGImoto}

(Figs. 5 and 6) and PAS stain (Fig. 16). The outer surface and broken surface of the starch grain ingested in the endoplasm of ciliate was changeless (Figs. 21 and 22).

From $1 \mathrm{~h}$ after the addition of starch, periphery of some of the ingested starch grains in the ciliate body became rough (Figs. 7 and 23). After $3 \mathrm{~h}$, surface of most of engulfed starch grains became rough (Fig. 8).

At $6 \mathrm{~h}$ after the addition of starch, some parts stained brownish by iodine staining appeared at the periphery of engulfed starch grains and the ectoplasm of ciliates in several individuals (Fig. 9), and at $9 \mathrm{~h}$, most of entodinia became in the similar condition. The ingested starch grains in the ciliate body became gradually small (Fig. 10), and hollows were observed on the surface of engulfed starch (Fig. 24). After $12 \mathrm{~h}$, the starch grains became smaller and the parts stained brownish in the ectoplasm became extended and darkened (Fig. 11).

\section{Explanation of Figures}

Figs. $4 \sim 15$. Light microscopy of degradation of strach grains engulfed by entodinia. Iodine staining. All figures are $\times 550$.

Fig. 4. After the starvation for $24 \mathrm{~h}$. Both the ectoplasm and the endoplasm of ciliate are stained light yellowish.

Fig. 5. Soon after the addition of starch. The starch grains stained dark violet are immediately ingested by ciliates.

Fig. 6. After $5 \mathrm{~min}$.

Fig. 7. After $1 \mathrm{~h}$.

Fig. 8. After $3 \mathrm{~h}$.

Fig. 9. After $6 \mathrm{~h}$. Some parts stained brownish appear at the periphery of engulfed starch grains and the ectoplasm of ciliate.

Fig. 10. After $9 \mathrm{~h}$.

Fig. 11. After $12 \mathrm{~h}$. The starch grains are small in size and the parts stained brownish are darkened and extended.

Fig. 12. After $24 \mathrm{~h}$. The starch grains engulfed are very small.

Fig. 13. After $48 \mathrm{~h}$. No starch grains are observed in the endoplasm.

Fig. 14. After $72 \mathrm{~h}$. The area stained brownish is narrower and light in color.

Fig. 15. After $96 \mathrm{~h}$. The ciliate is stained light yellowish.

Figs. 16 19. Light microscopy of degradation of starch grains engulfed by entodinia. PAS staining. All figures are $\times 600$.

Fig. 16. After $5 \mathrm{~min}$. No parts stained by PAS are observed.

Fig. 17. After $24 \mathrm{~h}$. The parts stained reddish are observed at periphery of the starch grains and the ectoplasm.

Fig. 18. After $48 \mathrm{~h}$. The parts of ectoplasm stained reddish.

Fig. 19. After 72 h. No parts stained reddish are existed.

Figs. 20 27. Scanning electron microscopy of the ingestion of starch grains by entodinia.

Fig. 20. Soon after the addition of starch. View from the anterior end of the ciliate. A starch grain has iust ingested. $\times 1,600$.

Figs. 21 and 22. After $5 \mathrm{~min}$. The outer surface and broken surface of engulfed starch are smooth. Fig. 21. $\times 1,800$. Fig. 22. $\times 1,700$.

Fig. 23. After $1 \mathrm{~h}$. The surface of engulfed starch is slightly rough. $\times 1,800$.

Fig. 24. After $9 \mathrm{~h}$. Inside of an upper starch is empty. $\times 1,800$.

Fig. 25. After 24h. Many spindle-shaped granular substances (arrows) are present at the ectoplasm. $\times 2,000$.

Figs. 26 and 27. After $48 \mathrm{~h}$. Starch grains almost degraded in the endoplasm are shown (arrows), Fig. 26. $\times 2,100$. Fig. 27. $\times 1,600$. 
Utilization of Starch Grain by Entodinium
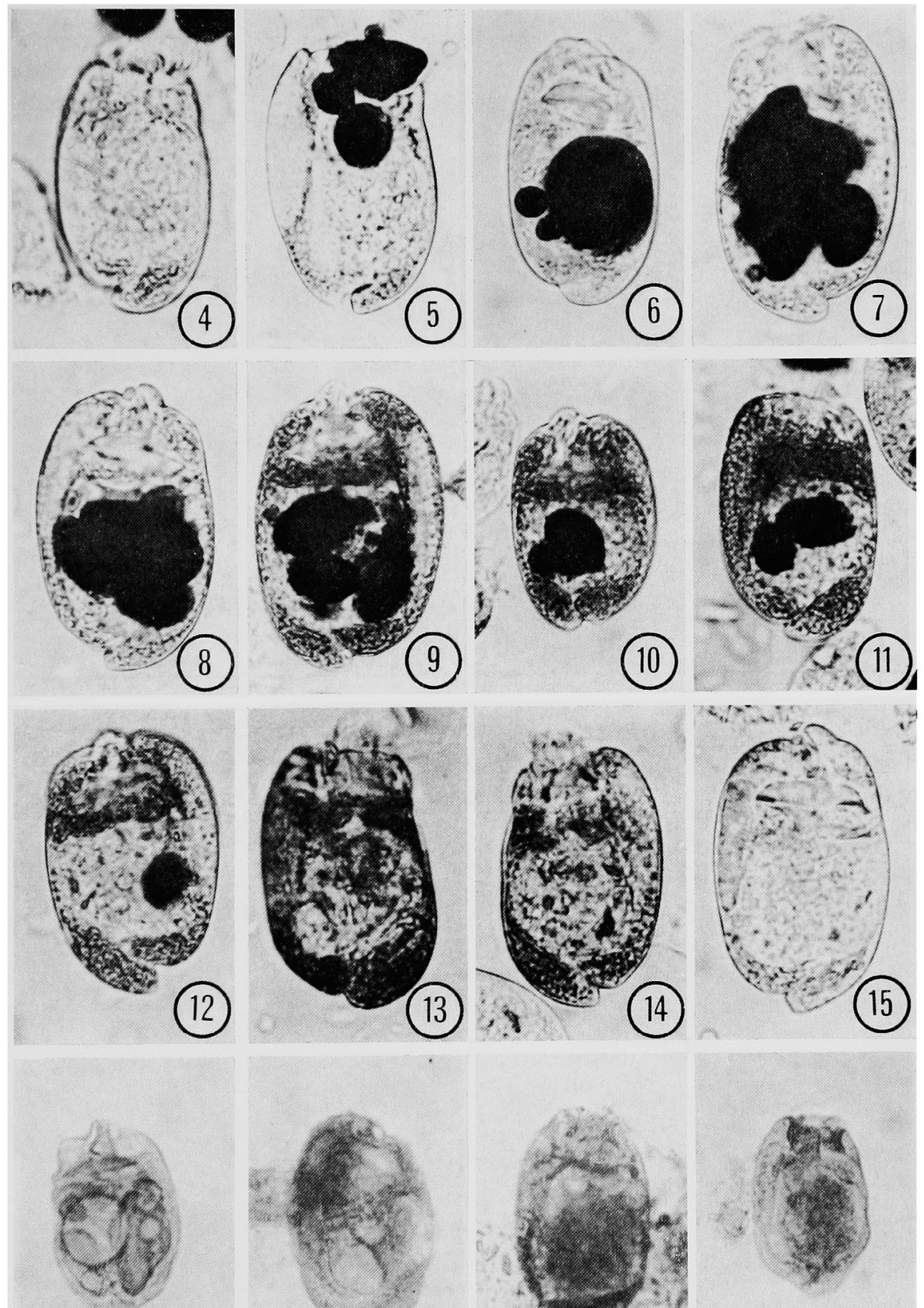

(16)
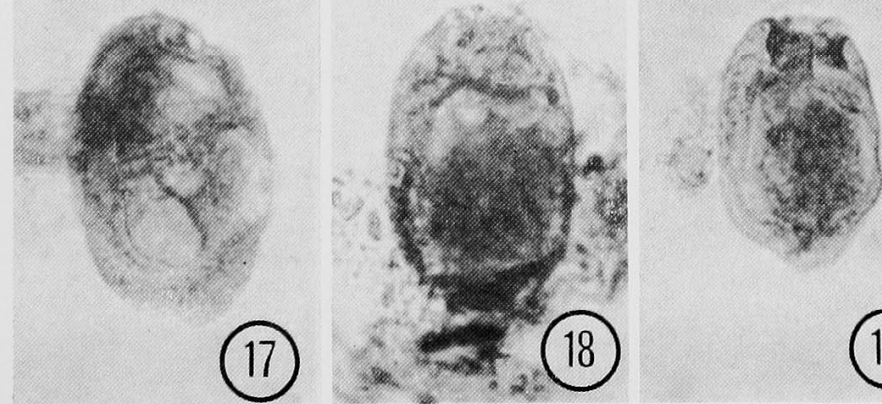

(19) 
Kinoshita, Imai, Ishil and Ogimoto
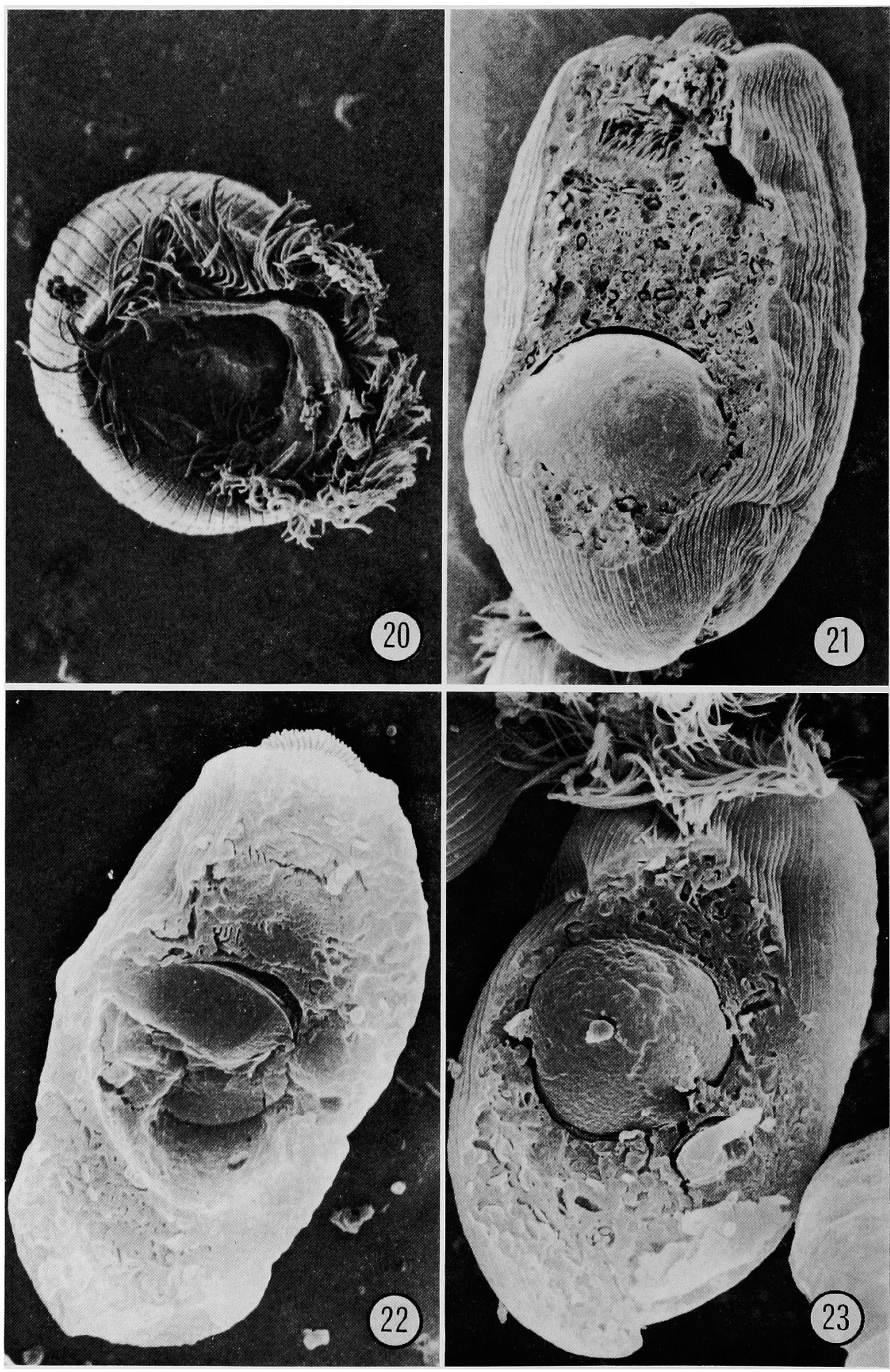

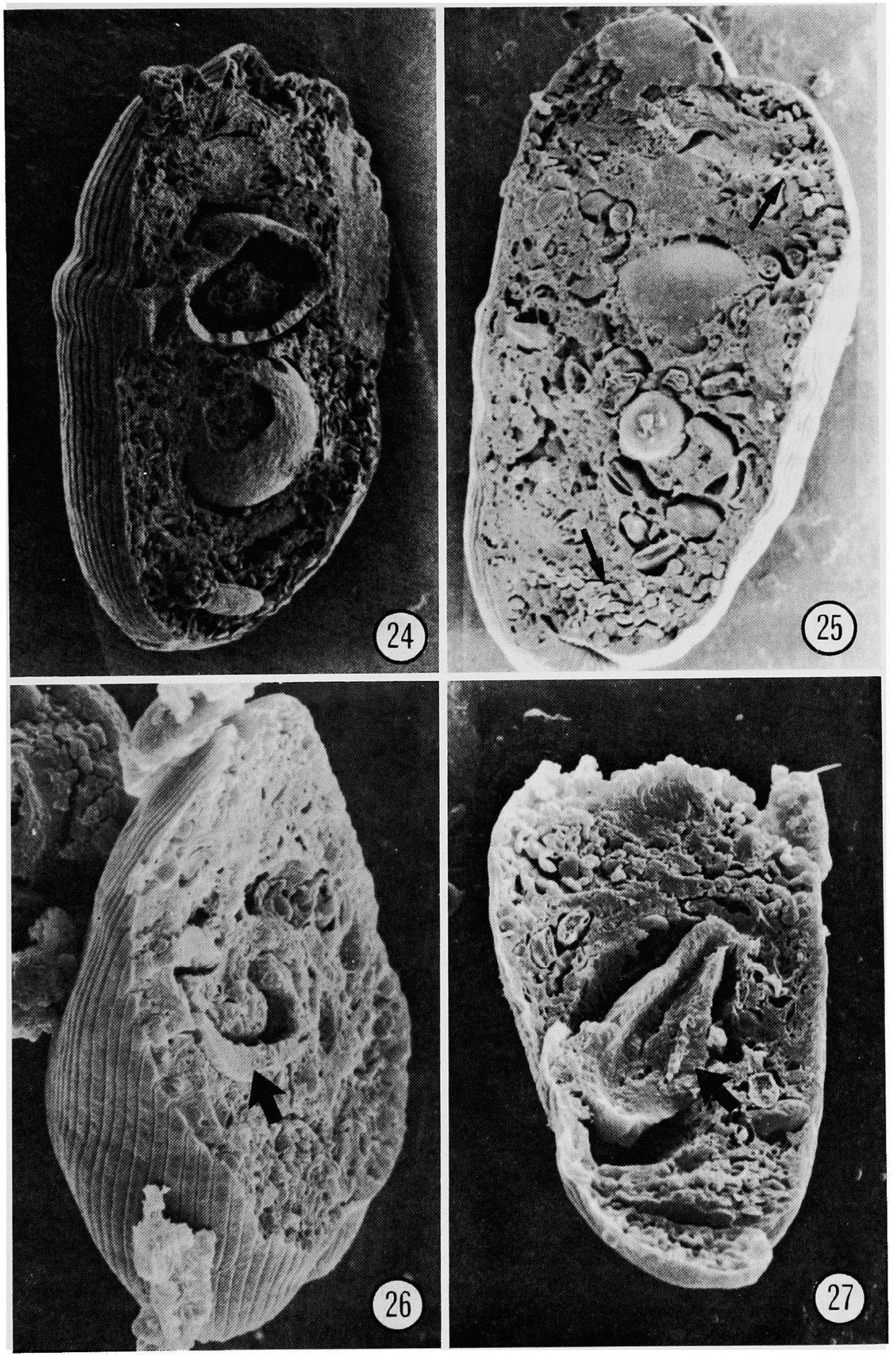
After $24 \mathrm{~h}$, the starch grains engulfed became very small in size and the area stained brownish by iodine staining further extended (Fig. 12). The parts stained reddish by PAS stain appeared at the periphery of the starch grains and the ectoplasm of ciliates (Fig. 17). Many spindle-shaped granular substances were observed in the ectoplasm of ciliates (Fig. 25).

After $48 \mathrm{~h}$, engulfed starch grains became very small and even disappeared in some ciliates (Fig. 13). The ectoplasm was distinctly stained reddish by PAS stain (Fig. 18). In SEM observation of the starch at that time, inside of some starch grains was empty, and many spindle-shaped granular substances were existed in the ectoplasm of ciliates (Figs. 26 and 27).

After $72 \mathrm{~h}$, starch grains disappeared in almost of ciliates and the area stained brownish in the ectoplasm of ciliates became narrower and light in color (Fig. 14). The parts stained reddish by PAS stain also disappeared in almost ciliates (Fig. 19). After $96 \mathrm{~h}$, no ciliates possessed the area stained by iodine staining. These ciliates were uniformly stained as well as the ciliates starved.

\section{Discussion}

From the result of the cultivation of rumen ciliates with various kinds of starch grains, differences in the condition of maintenance of the ciliates were recognized among the kind of starch, that is, most favorable maintenance was performed in the case of addition of rice starch, and disadvantageous maintenance of the ciliates was in the cases of addition of soluble starch and potato starch.

It was considered that the difference in the growth of each ciliate species by the kind of starch grains which had almost same chemical structure was due to the relation between the sizes of strach grains and of the oral zone of ciliates. Since the mean diameter of rice starch was $4.4 \mu \mathrm{m}$, it was considered that $E$. nanellum which was one of the smallest ophryoscolecid ciliates with a mouth about $16.0 \mu \mathrm{m}$ in mean diameter could engulf easily almost of the grains. In contrast, the sizes of potato starch and soluble starch were over $40 \mu \mathrm{m}$ and larger than the mouth of E.caudatum which was one of the ciliates with the biggest mouth in this examination.

The maintenance of small entodinia by wheat starch and corn starch was more disadvantageous than in the case of rice starch, although the mean diameters of these starch were smaller than that of the mouth of small entodinia. Since the mean diameters of these starch were about two times of rice starch, the assimilation of these grains might be somewhat difficult for small entodinia such as $E$. nanellum and $E$. parvum. The reason that E.parvum decreased even in the culture with wheat starch which had fairly smaller diameter than that of the mouth of E. parvum was obscure. However, it may be related to a competition with large entodinia, such as $E$. caudatum, for the engulf of starch. In addition, the ciliates in the cultures with potato starch and soluble starch did not disappeared. It was considered for this reason that small strach grains could be engulfed by ciliates since the size of the grains of these starch was unequal. 
As shown in Table 1 which presents the relation between the size of starch grains and the growth of ciliates, it is concluded that the ability of assimilation of starch is closely related to the size of starch grains.

The starch grains engulfed by entodiniid ciliates became smaller in size with the lapse of time, and disappeared from the ciliate body at $72 \mathrm{~h}$ after the addition of starch. Following the decrease in size of the starch, many spindle-shaped granular substances which were stained brownish by iodine staining and reddish by PAS stain, appeared in the ectoplasm of the ciliates. After that, these substances also decreased with the lapse of time. From the results, it is suggested that the starch grains ingested by the ciliates are digested in the endoplasm and synthesized to spindle-shaped granular substances. These substances were assumed to be used as energy source of ciliates.

The entodiniid ciliates previously starved for $24 \mathrm{~h}$ after the collection from the rumen ingested starch grains as soon as those were inoculated in the media with starch. The ingested time was very short, i. e., within $1 \mathrm{~min}$ in a half of the ciliates. This fact suggests that the motional function of the cilia is extremely superior for the catching of the granular carbohydrates. This is supported by the study of the adoral ciliary zone of Entodinium using $\mathrm{SEM}^{12}$. This function may be highly related to the fact that the entodiniid ciliates utilize particulate starch as almost only their carbohydrate nutrient ${ }^{6}$.

The process of digestion of starch grains by entodiniid ciliates observed in this examination roughly agreed with the in vivo investigation ${ }^{13)}$, where the ciliates collected from the sheep kept without starch for a given period of time and than supplied with starch were observed light microscopically. However, the digestion time of starch by the ciliates was slightly longer in the present examination than in the in vivo investigation ${ }^{13)}$. It is considered that this delay is due to the different environmental conditions, such as the fall of $\mathrm{pH}$, change of bacterial flora and lack of nutrients other than starch, in the media. Consequently, the ability of digestion of the ciliates in vitro might be declined.

It is considered that the spindle-shaped granular substances appeared in the ectoplasm of ciliates are amylopectin ${ }^{14)}$ and that those are reserve substances of carbohydrate nutrient for the ciliates.

\section{Acknowledgments}

The authors wish to thank Mr. H. TASHIRo, of the Department of Parasitology, Nippon Veterinary and Zootechnical College, for his technical assistance for scanning electron microscopy.

\section{References}

1) Hungate, R. E., The Rumen and Its Microbes. Academic Press. New York. 1966.

2) Quinn, L. K., W. Burroughs and C. Christransen, Appl. Microbiol., 10: 583-592. 1962.

3) Onodera, R. and M. Kandatsu, Jpn. J. Zootech. Sci., 40: 14-21. 1970.

4) Hungate, R. E., Biol. Bull., 84: 157-163. 1943. 
5) Sugden, B., J. Gen. Microbiol., 7: 145-153. 1953.

6) Авоu-Aккара, A.R. and B. H. Howard, Biochem. J., 76: 445-451. 1960.

7) Hungate, R. E., Biol. Bull., 83: 303-319. 1942.

8) Imai, S., M. Katsuno and K. Ogrmoto, Bull. Nippon Vet. Zootech. Coll, 28: 69-74. 1979.

9) Imai, S., M. Katsuno and K. Ogrmoto, Bull. Nippon Vet. Zootech. Coll., 28: 75-83. 1979.

10) Ogimoto, K. and S. Imal, Atlas of Rumen Microbiology. Japan Scientific Societies Press. Tokyo. 1981.

11) Imai, S. and H. TAshiro, Trans. Am. Microsc. Soc, 101: 299-302. 1982.

12) Imai, S., H. Tashiro and T. Ishil, J. Protozool., 30: 466-472. 1983.

13) Van der Wath, J. G. and S. J. Myburgh, Onderstepoort J. Vet. Sci., 17: 61-85. 1943.

14) Eadie, J. M., D. J. Manners and J. R. Stark, Biochem. J., 89: 919-929. 1963.

\title{
In vitro における Entodinium 属䋐毛虫による デンプン粒の利用に関する機能形態学的観察
}

\author{
木下正保 -今井壮一 - 不井俊雄 - 扇元敬司* \\ 日本獣医育産大学素生虫学教室, 武蔵野沁 180 \\ *東北大学柰学部家畜街生学教室, 仙台方 980
}

\begin{abstract}
In vitroにおける Entodinium 属の增殖に及ぼすデン プン粒の種頑の検討と, 取り込まれたデンプン粒の運命 について形態学的に钼察を行なった. Entodinium 属繊 毛虫の增殖はデンプンの種類および織毛虫種によって異 なり，デンプンの種颣では米デンブンのような小型の粒 子をもつものが，㐬た纎毛虫種では E. caudatum のよ らな大型のるの卧ど增殖が良好な傾问が見られた，そこ で, 瀻毛虫の口部と各デンプン粒子の大きさとを測定し， 先に得られた增殖との関連を㛟討したところ，Entodinium によるデンプンの取り込みには，デンプン粒子の
\end{abstract}

大きさと緎毛虫の口部の大きさがかなり密接に関連して いることが明らかとなった.

絨毛虫は添加デンブン粒子をきわめて短時間（5分以 内）に取り込及，内質内に数個の粒子を眝蔵したが，培 養 6 時閒以降にはデンプン粒子の分解が見られ，粒子が 小型化していくと共に外質内にヨート゚染色で茶褐色に染 色される米粒状を呈する物質が形成された，さらに飢餓 培羑を続けると，48 時間啳にはこの物質も消失したこと から，本物質は㵶毛虫の貯蔵多糖であると考之られた。

日荅会報，55（11）：864-876，1984 